|| ISSN(online): 2589-8698 || ISSN(print): 2589-868X ||

International Journal of Medical and Biomedical Studies

Available Online at www.ijmbs.info

PubMed (National Library of Medicine ID: 101738825)

Index Copernicus Value 2018: 75.71

Volume 3, Issue 10; October: 2019; Page No. 30-32

\title{
STUDY OF RENAL FUNCTION TEST IN CHILDREN WITH MALARIA
}

\section{Dr. Abender Singh Maanju ${ }^{1}$, Dr. K C Verma ${ }^{2^{*}}$}

${ }^{1}$ Assistant Professor, Department of Paediatric, JNU Institute for Medical Sciences and Research Centre, Jaipur

${ }^{2}$ Associate Professor Department of Community Medicine, JNU Institute for Medical Sciences and Research Centre, Jaipur

Article Info: Received 25 August 2019; Accepted 04 September 2019

DOI: https://doi.org/10.32553/ijmbs.v3i10.592

Address for Correspondence: Dr. K C Verma Associate Professor Department of Community Medicine, JNU Institute for Medical Sciences and Research Centre, Jaipur

Conflict of interest: No conflict of interest.

\begin{abstract}
Background: Malaria is a disease of global importance having effect on more than ninety countries and territories in the tropical and subtropical region of earth. Objectives: This study was undertaken to assess the renal functions in children with malaria.

Methods: Sixty children with smear positive malaria were included in this study. Detailed history regarding main renal manifestations was obtained. Renal function was assessed by gfr, blood urea and serum creatinine. It is compared with 25 age and sex matched healthy controls.

Results: proteinuria was documented in $42 \%$ of cases and it was common with falciparum infection. blood urea and serum creatinine were significantly high in malaria cases compare to controls.

Conclusion: The evaluation of renal functions in malaria infected children should form an important part of assessment because of variety of acute onset renal dysfunction. In addition it may facilitate safer use of fluids and drugs study also showed that renal dysfunction found in human malaria.
\end{abstract}

Keywords: Acute renal failure, acute respiratory distress syndrome, glomerularfilteration rate.

\section{Introduction:}

Anaemia Malaria is a disease of global importance and affects population of more than ninety countries and territories of the tropical and subtropical areas. According to the World malaria report 2011, there were about 216 million cases of malaria (with an uncertainty range of 149 million to 274 million) and an estimated 655000 deaths in 2010 (with an uncertainty range of 537000 to 907000 ). Mortality rates due to malaria have fallen by more than $25 \%$ globally since 2000 , and by $33 \%$ in the WHO African Region. Most deaths occur among children living in Africa where every minute a child dies from malaria. (1)

Malaria is one of oldest recorded disease known to human. The term "Malaria "came into use in the 18th century from Italy. Malaria is an Italian word composed of "mala" and "aria," derived from malus (bad), and aeris (air). The term was first used to describe a fever (miasma), which was wrongly attributed to exposure to poisonous air rising from marshes. (2)
Malaria is caused by four species of Plasmodium these are Plasmodium vivax, P. falciparum, P. malariae and $P$. ovale. Common clinical symptoms of infection with all above Plasmodia species are periodic paroxysm, chills, rigors, sweating, body aches, headache, nausea, generalised weakness and prostration. Severe life-threatening complications like cerebral malaria, severe anemia, respiratory distress, jaundice, acidosis, acute renal failure (ARF), acute respiratory distress syndrome (ARDS), etc occur mostly due to $P$. falciparum infection.

Renal involvement in malaria cases vary from mild proteinuria to severe renal failure. Clinically significant renal and related disorders are most commonly seen in infection with plasmodium falciparum and recently due to $P$. vivax infections. The knowledge of renal function is important for clinical management of patients with malaria, including monitoring of drug dosage and fluid balance.

\section{Material and methods}

The present study was done from January 2014 to July 2014 in department of Paediatrics at Military Hospital Jaipur. Sixty children admitted at Military 
Hospital Jaipur with smear positive malaria cases were included in the study using purposive sampling technique.

Inclusion criteria: All Children less than 15 yrs of age diagnosed as malaria patients were included in our study. Exclusion criteria: Children with pre-existing renal disease, Children taking any medication which known to cause renal impairment and Children with past history of renal disease that could interfere in our study.

The purpose of the study and details of protocol were discussed with the parents and an informed written consent was obtained. Detailed history regarding various clinical manifestations was elicited. Detailed clinical examination was done. After obtaining history and physical examination, blood and urine samples were obtained for investigation.

Renal function was assessed by blood urea, serum creatinine and GFR. GFR was calculated by using Schwartz formula. This method avoids need for a collection of urine and is more accurate than creatinine clearance. These parameters were compared with 25 age and sex matched healthy people.

\section{Statistical analysis:}

Collected data was analysed by frequencies, percentages, Mean, standard deviation, Chi-square test and Anova test. $P$ value $\leq 0.05$ was considered significant.

\section{Results}

All the patients in this study were diagnosed to be cases of malaria by Peripheral smear examination. These investigations were ordered before the antimalarial treatment was started. 25 age sex matched healthy children were taken as controls.

Table no. 1 and 2 shows blood urea and creatinine level in patients suffering from malaria were significantly increased $(p-<0.001)$.

Table no. 4 shows GFR value is significantly decreased in malarial patients as compared to healthy controls.

Table 1: blood urea level in cases and control

\begin{tabular}{|l|l|l|}
\hline Blood urea(mg/dl) & Cases & Control \\
\hline$<\mathbf{2 0}$ & 16 & 16 \\
\hline $\mathbf{2 0 - 4 0}$ & 33 & 09 \\
\hline$>\mathbf{4 0}$ & 11 & 00 \\
\hline
\end{tabular}

Table 2: serum creatinine level in cases and control

\begin{tabular}{|l|l|l|}
\hline Serum Creatinine(mg/dl) & Cases & Control \\
\hline$<\mathbf{1}$ & 52 & 25 \\
\hline $\mathbf{1 - 2}$ & 08 & 00 \\
\hline$>\mathbf{2}$ & 00 & 00 \\
\hline
\end{tabular}

Table 3: GFR level in cases and control

\begin{tabular}{|l|l|l|}
\hline GFR (ml/min.) & Cases & Control \\
\hline$<\mathbf{9 0}$ & 32 & 01 \\
\hline $\mathbf{9 0 - 1 2 0}>120$ & 18 & 18 \\
\hline & 10 & 06 \\
\hline
\end{tabular}

Table 4: comparison of mean levels of blood urea, serum creatinine and GFR levels between cases and control

\begin{tabular}{|l|l|l|l|}
\hline Group & Number & Mean+sd & p value \\
\hline $\begin{array}{l}\text { Blood urea } \\
\text { Case }\end{array}$ & 60 & $31.15 \pm 8.87$ & $\mathrm{P}<0.001$ \\
Control & 25 & $18.32 \pm 3.39$ & \\
\hline $\begin{array}{l}\text { Serum creatinine } \\
\text { Case }\end{array}$ & 60 & $0.77 \pm 0.24$ & $\mathrm{P}<0.001$ \\
Control & 25 & $0.58 \pm 0.1$ & \\
\hline FGR & & & \\
Case & 60 & $91.43 \pm 27$ & $\mathrm{P}<0.001$ \\
Control & 25 & $114.28 \pm 15$ & \\
\hline
\end{tabular}

$P$ value - highly significant

\section{Discussion}

Malaria is the most common serious parasitic disease of human beings, transmitted by mosquitoes. It is caused by plasmodium species found all over the world and is endemic in many tropical countries. 300500 million cases of malaria occur annually all over the world with an estimated 1.1-2.7 million deaths each year, killing one-person every 30 seconds.(3) Malaria is third disease among the major infectious diseases in the world which causes death of people after pneumococcal acute respiratory infections and tuberculosis. It carry about 2.6 percent of the total disease burden of the world. It is responsible for the loss of more than 35 million disability-adjusted lifeyears each year. Every year around 30000 visitors to endemic areas develop malaria and $1 \%$ of them may die. $(4,5)$

Malaria is a major health problem in India. Approximately 2.48 million cases are reported annually from South-east Asia, of which $75 \%$ cases are contributed by India alone. WHO has reported malaria mortality rate 15000 per year in India; however, A study done by "million death collaborators" suggest that there is much higher annual malarial mortality from malaria in India $(205,000$ overall and 55,000 in children $<14$ y age). (6, 7)

In present study mean blood urea, mean serum creatinine was significantly high in malaria cases compared to control. Similar results were reported by Ekeanyanwu RC et al(8), Ogbadoyi EO et al (9) and 
Idonije $\mathrm{BO}$ et al(10) in their studies with respect to serum urea, but Ogbadoyi EO et al (9) in their study failed to show any significant difference between the serum creatinine levels in malaria patients when compare to healthy controls.

Studies by Ogbadoyi EO et al (9) and Idonije BO et al (11) had also reported that serum urea changes seen commonly with female patients who had malaria. This observation was not seen in our study.

Study done by Umboh A et al (12) had reported that blood urea increases with severity of infection, but not creatinine. However our study showed mean Blood urea and mean serum creatinine increases as severity of malaria increases. In contrary, study done by Adenosun OG et al (13) showed that there was no significant correlation between blood urea with severity of infection.

In our study $53 \%$ of cases had renal impairment during acute illness. This is

contrary to study done at Aligarh (India) by Ahmad SH (14), where $83 \%$ of cases had impairment of renal function during acute illness. However the study conducted by Sowunmi A (15) revealed that impairment of renal function was seen in $45 \%$ of cases. Our study has not showed any significant relationship between low GFR $(<90 \mathrm{ml} / \mathrm{kg} / 1.73 \mathrm{~m} 2)$ level and malaria species or severity of infection. This is just similar with findings of Umboh A et al (12).

\section{References}

1. Malaria fact sheet April 2012 [online] Available from:

URL:http://www.who.int/mediacentre/factsheet s/fs094/en/ [Accessed on may 28,2012].

2. Barsoum RS. Malarial Acute Renal Failure. J Am SocNephrol 2000;11:2147-2154

3. Tripathy R, Parida S, Das L, Mishra DP, Tripathy $D$, Das $M C$ et al. Clinicalmanifestations and predictors of severe malaria in Indian children Pediatrics2007;120(3):454-460

4. Crawley J, Chu C, Mtove G, Nosten F. malaria in children. Lancet 2010;375:1468-81

5. Kochar DK, TanwarGS, Khatri PC, Kochar SK, SengarGS, Gupta A et al. Clinical features of children hospitalised with malaria- A study from BikanerNorthwest India. Am J Med. Hyg2010;83(5):981-989

6. Yadav D, Chandra J, Aneja S, Kumar V, Kumar P, Dutta AK. Changing profile ofsevere malaria in north Indian children, Indian J Pediatr 2010;79(4):483-487

7. Ritabrata K. Management of malaria in children: Update 2008, IAP infectiousdiseases chapter. Indian Pediatr 2008; 45: 731-735

8. Raphael EC, Benjamin AU. Assessment of renal function of Plasmodium falciparum infected children in Owerri, Eastern Nigeria. Research Journal of Medical Sciences 2010;4(3):208-212

9. Ogbadoyi EO, Gabi B. Assessment of renal function in malaria patients in Minia, North General Nigeria. Afr. J. Infectious disease 2007;1(1);57-64

10. Idonije BO, NwokeEO, Festus O, Oluba OM. Plasma concentration of kidney function indicators in malaria patients in Ekpoma SouthSouth Nigeria. International Journal of Tropical Medicine 2011;6(1):4-7

11. UzuegbuUE. Serum electrolytes and urea changes in P. falciparum malarial infected Children in Nigeria. Asian Journal of Medical Sciences 2011;3(2):50-51

12. Umboh A, Muljinto $S$, WibisonoJS. Association between plasmodium falciparumparasite index and renal function in children. Paediatrica indonesiana 2003;43(56):91-94

13. Adeosun OG, Oduola $T$, Akanji BO, Sunday AM, UdohSJ, Bello IS. Biochemical alteration in Nigerian children with acute falciparum malaria. African Journal of Biotechnology 2007;6(7):881885

14. Ahmad SH, Danish T, Faridi MMA, Ahmad AJ, Fakhir S, Khan AS. Renal function in acute malaria in children. J Trop Pediatr.1989;35:291294

15. Sowunumi A. Renal function in acute falciparum malaria. Archives of Disease in Childhood 1996; 74:293-298 